\title{
The Application of Lipoic Acid in Experimentally Induced Tympanosclerosis in Rats
}

\section{Ratlarda Deneyse Olarak Oluşturulan İnfilamasyonla İlişkili Timpanoskleroza Alfa Lipoik Asidin Etkisi}

\author{
Fatih Turan', (i) Ilyas Sayar2, (1) İsmail Salcan³ \\ 'Sakarya University Traning and Research Hospital Department of Otorhinolaryngology, Sakarya, Turkey. \\ ${ }^{2}$ Erzincan University School of Medicine Department of Pathology, Erzincan, Turkey \\ ${ }^{3}$ Erzincan Mengücekgazi Traning and Research Hospital Department of Otorhinolaryngology, Erzincan, Turkey
}

\begin{abstract}
Objectives: Tympanosclerosis is an abnormal tissue reaction resulting in sclerotic and hyalinization changes in the tympanic membrane and middle ear. We hypothesized that alpha lipoic acid, an antioxidant, may represent a simple and effective form of treatment in inflammation-related tympanosclerosis. The purpose of the study was to investigate the effects of alpha lipoic acid on experimentally induced inflammation-related tympanosclerosis in rats.

Material and Method: Twenty albino Wistar rats were randomly divided into two equal groups. The first (study) group was administered $50 \mathrm{mg} / \mathrm{kg}$ alpha lipoic acid by the intraperitoneal route once daily for 7 days. The second group was administered the same saline solution intraperitoneally once daily for 7 days. Inflammation, fibrosis and lamina propria thickness were assessed at the subsequent histopathological examination.
\end{abstract}

Results: In the study group, significantly less middle ear inflammation and fibrosis developed and the tympanic membrane lamina propria was thinner compared to the control group.

Conclusions: Alpha lipoic acid was found capable of preventing experimentally induced inflammation-related tympanosclerosis with its antioxidant characteristics.

Keywords: Alpha-Lipoic acid; inflammation; fibrosis.
Öz

Amaç: Timpanoskleroz timpanik membran ve orta kulak mukozasının sklerotik ve hiyalinize değişikliği ile giden anormal bir doku reaksiyonudur. Bir antioksidan olan alfa lipoik asidin, inflamasyonla ile ilişkili timpanosklerozda basit ve etkili bir tedavi biçimini temsil edebileceğini varsaydık. Çalışmanın amacı, alfa lipoik asidin sıçanlarda deneysel olarak indüklenen infilamasyon ile ilşkili timpanoskleroz üzerindeki etkilerini araştırmaktı.

Gereç ve Yöntem:Çalışmamızda 20 adet Wistar albino sıçan kullanıldı. Sıçanlar rastgele olarak onarlı iki gruba ayrıldı. 1. gruba ALA 50 mg/kg yedi gün boyunca günde bir defa intraperitoneal uygulandı. 2. gruba salin aynı miktarda yedi gün boyunca günde bir defa intraperitone al uygulandı. Histopatolojik olarak değerlendirmemizde inflamasyon, fibrozis ve lamina propria kalınlığı değerlendirildi.

Bulgular: Orta kulakta enflamasyon, fibrozis ve timpanik membran lamina propria kalınlığı değerlendirildiğinde, çalışma grubunda kontrol gurubuna göre daha az olduğu değerlendirildi.

Sonuç: Antiokstidan özellik gösteren alfa lipoik asit'in deneysel olarak oluşturulmuş inflamasyonla ile ilişkili timpanosklerozu önleyebileceği görüldü.

Anahtar Kelimeler: Alfa-Lipoik asit, inflamasyon, fibroz

Corresponding (illetişim): Fatih Turan, Sakarya University Traning and Research Hospital Department of Otorhinolaryngology, Sakarya, Turkey E-mail (E-posta): turantf@hotmail.com 


\section{INTRODUCTION}

Tympanosclerosis (Ts) is an abnormal tissue reaction resulting in sclerotic and hyalinization changes in the tympanic membrane and middle ear. A homogeneous mass emerges due to the thickening and fusion of the collagen fibrils in the submucosal lamina propria. The condition described as Ts results from an accumulation of intraand extracellular calcium and phosphate. Deposition around the middle ear structures and ossicular system may increase with the sclerosis and result in a diffuse state, which is difficult to treat. ${ }^{[1]}$

The cause of Ts and how it develops are still not clear. However, the factors implicated in the etiology include myringotomy, ventilation tube placement, middle ear infections, effusive otitis, trauma, immune response, Eustachian function impairment, hypersensitivity, genetic predisposition and local metabolic changes. ${ }^{[2]}$

Studies investigating the etiology of inflammation-related Ts development have shown that increased environmental oxygen levels and the formation of free oxygen radicals are among the significant factors involved.

Many inflammatory cells, particularly polymorphic nucleus leukocytes and macrophages, produce free oxygen radicals. Under normal conditions, the human middle ear cavity contains 5 to $10 \%$ oxygen. ${ }^{[3]}$ This may rise up to $21 \%$ following tympanic membrane perforation or the use of ventilation tubes, which allow external air into the middle ear cavity, leading to hypoxia. The increased production of free oxygen radicals associated with hypoxia initiates a process involved in the formation of sclerotic plaques. ${ }^{[3,4]}$

Alpha lipoic acid (ALA) is a natural compound synthesized with the enzyme lipoyl synthase from 8-carbon fatty acids (octanoic acid) in humans. ALA and its reduced form in the body, dihydrolipoic acid (DHLA), may be present as an antioxidant in hydrophilic and lipophilic environments. ${ }^{[5]}$ In vivo and in vitro studies have shown the antioxidant effects of ALA. This compound scavenges hydroxyl radical and hypochloric acid but has little effect on superoxide and peroxide radical. ${ }^{[6]}$ Both ALA and DHLA affect hydrogen peroxide and oxygen radicals, and can act as a good metal chelator. Furthermore, ALA, which is a moderate antioxidant, and DHLA which is regarded as the best antioxidant, remove heavy metals in the biological system by forming stable compounds with transition metals such as $\mathrm{Mn}^{+2}, \mathrm{Cu}^{+2}, \mathrm{Zn}^{+2}$ and $\mathrm{Pb}^{+2} \cdot$. 7$]$

ALA is widely applied for various treatment diseases, including heart disease, tumors, hepatitis, diabetes and related complications. ${ }^{[7,8]}$ Since ALA is ingested with the daily diet, reduces the harmful effects of heavy metals and exhibits antioxidant activities, we hypothesized that it may represent a simple and effective form of treatment for inflammationrelated Ts. The purpose of the study was to investigate the effects of ALA as an antioxidant on experimentally induced inflammation-related Ts in rats.

\section{MATERIAL AND METHOD}

Twenty male albino Wistar rats weighing 200-250 g were used. The subjects were kept in plastic cages in a light-dark (12/12) cycle at $22 \pm 3{ }^{\circ} \mathrm{C}$ and a humidity of $65-70 \%$. Rats were allowed ad libitum access to standard laboratory chow and water, and were housed under conditions compatible with the'Principles Regarding the Care and Use of Laboratory Animals'. Ethical committee approval was obtained to conduct the study (2013 HADYEK 018) in the Experimental Medicine Research laboratory of Gaziosmanpaşa University, Turkey.

\section{Study protocol}

Rats that had no outer and middle ear pathology at otomicroscopic examination were excluded from the study. A Streptococcus pneumoniae strain was obtained from patients in Erzincan University Mengücek Gazi Education and Research Hospital and stored at -80 degrees in the hospital's microbiology laboratory. This strain was then cultured on sheep's blood agar (OXOID LTD., Basingstoke, Hampshire, ENGLAND) prepared in the laboratory and incubated for $24 \mathrm{~h}$ in a stove (SANYO Electric Co., JAPAN) containing $5 \%$ carbon dioxide. Then, a bacterial suspension ( $0.5 \mathrm{McF}$ (arland standard) was prepared in brain heart infusion broth (OXOID LTD, Basingstoke, Hampshire, ENGLAND) using the Streptococcus pneumoniae colonies produced. The suspension was injected into the middle ears of all rats under microscopy in order to induce Ts.

Rats were randomly assigned into two equal groups. The first (study) group was administered $50 \mathrm{mg} / \mathrm{kg}$ ALA by the intraperitoneal (i.p.) route once a day for 7 days. ${ }^{[9]}$ The second (control) group was administered the same saline solution i.p. once a day for 7 days.

Rats were monitored throughout the experimental period. Otomicroscopic examination was performed daily. Two rats from the study group and one from the control group were removed from the study on the third day since middle ear infection was not observed at otomicroscopic examination. These subjects were replaced by three rats that also underwent otomicroscopic examination before being randomly assigned to the groups and started on the appropriate medical treatment. All rats were anesthetized on the 8th day of the study with $50 \mathrm{mg} / \mathrm{kg}$ ketamine (Ketalar, Eczacıbaşı Warner Lambert, Istanbul, Turkey) and $5 \mathrm{mg} / \mathrm{kg}$ xylazine hydrochloride (Ksilazol, Provet Veteriner Ürünleri Sanayi, Istanbul, Turkey) through an i.p. injection. Following anesthesia, perfusion fixation was performed via the vascular system in order to establish more rapid and regular fixation. The rats were then sacrificed, and their temporal bones were removed.

\section{Histopathological analysis}

The temporal bones were stored in $10 \%$ formaldehyde for 24-48 h. The specimens were treated for 1.5 months in a decalcificationsolutioncontainingethylenediaminetetraacetic acid, which was changed once a week. After 1.5 months, the specimens were first kept in $100 \%$ alcohol for $2 \mathrm{~h}$, then the xylene solution was added in equal portions every 30 minutes over a period of $1.5 \mathrm{~h}$. Tissues were paraffin-embedded twice, for 2 and $3 \mathrm{~h}$, and placed in blocks. Sections, 5 and 20 microns in thickness, were prepared using a rotary microtome (LEICA), with at least 10 sections being taken from each specimen. The sections were grouped using systematic randomization and stained with Masson's trichrome for histological analysis.

Three criteria were employed in the histopathological analysis; inflammation in the lamina propria, fibrosis and lamina propria thickness. Inflammation and fibrosis in the middle ear were analyzed semi-quantitatively. Inflammatory and fibroblast cells 
measured in one field were counted and classified. No cells being observed in a field was categorized as 0 , fewer than 5 cells as + and more than 5 cells as ++ .

Data from sections stained with Masson's trichrome were transferred to a computer with a camera in order to measure the thickness of the middle ear lamina propria. Measurements were performed in micrometers by calibration at $10 x$ magnification. The means of these measurements were taken as the lamina propria thickness. In each group, middle ear lamina propria thickness was measured from five different points of the sections examined. These thicknesses were then compared within their respective group.

\section{Statistical analysis}

The study data was assessed using the SPSS program (PASW version 21). A parametric Student's t-test (or independent samples t-test) was used to analyze the thickness of the lamina propria since the distribution between the groups was normal. A chi-squared test was used to determine whether there were any differences between the groups in terms of inflammation and fibrosis. Since the values expected from chi-square assumptions were below 5, Fisher's exact test was performed.

\section{RESULTS}

In the histological analysis, fibrosis and inflammation was rare in the study group and extensive in the control group (Figures $\mathbf{1 , 2 , 3}$ ). Middle ear inflammation and fibrosis scores (Table 1) Iwere significantly lower in the study group compared to the control group $(\mathrm{p}<0.05)$ (Table 2, Figure 4). In addition, the lamina propria was significantly thinner in the study group compared to the control group $(p<0.05)$ (Table 3, Figure 5).

\begin{tabular}{|c|c|c|}
\hline & \multicolumn{2}{|c|}{ Histological evaluation } \\
\hline \multirow{3}{*}{ Inflammation score } & No cells & 0 \\
\hline & Fewer than 5 cells & 1 \\
\hline & More than 5 cells & 2 \\
\hline \multirow{3}{*}{ Fibrosis score } & No cells & 0 \\
\hline & Fewer than 5 cells & 1 \\
\hline & More than 5 cells & 2 \\
\hline
\end{tabular}

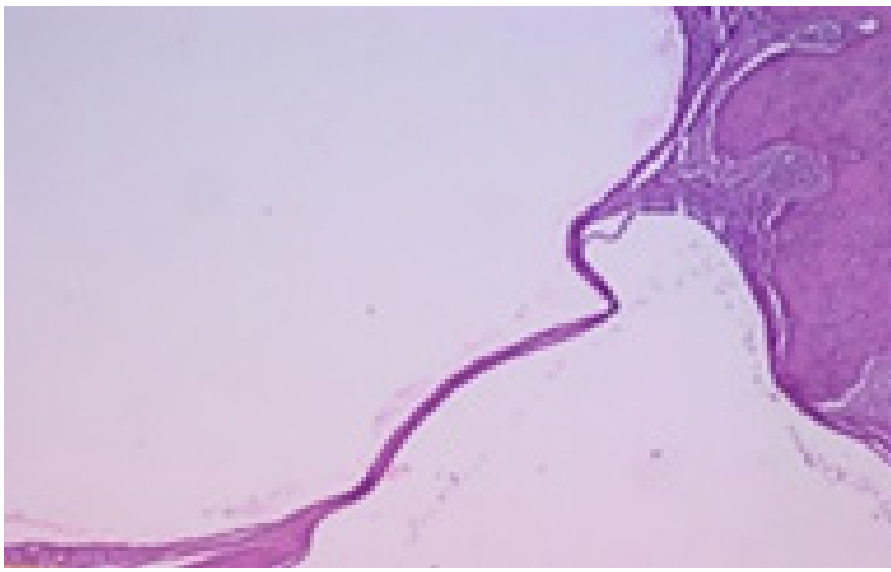

Figure 1. Extensive fibrosis and inflammation in the control group with $\mathrm{H}$ and E staining at $\times 20$ magnification

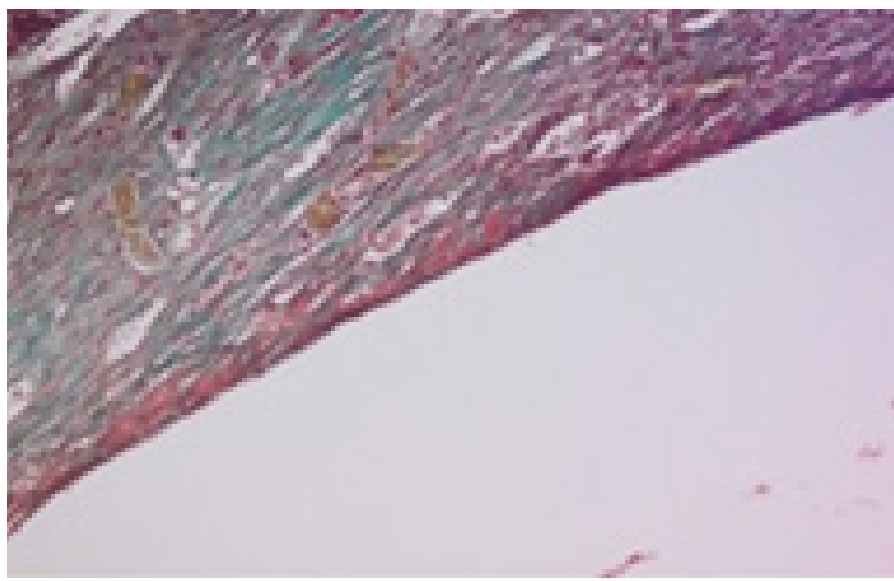

Figure 2. Diffuse fibrosis and inflammation in the control group at staining with Masson's trichrome at $\times 20$ magnification

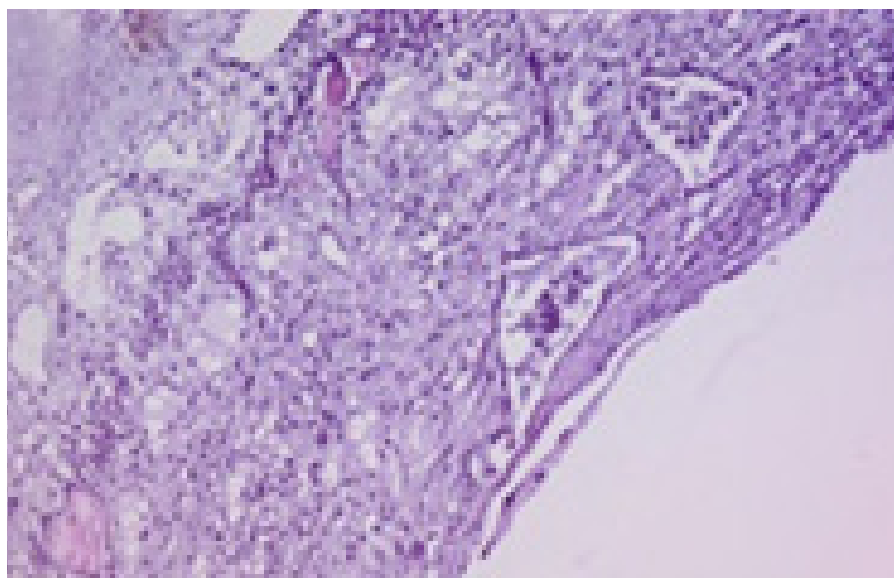

Figure 3. Fibrosis and inflammation in the group receiving alpha lipoic acid at staining with hematoxylin eosin at x10 magnification

Table 2. Distribution of inflammation and fibrosis scores between the study and control subjects.

\begin{tabular}{lcc} 
Experimental Subject & Inflammation Score & Fibrosis Score \\
\hline Study group subject (Sgs1) & 0 & 0 \\
Sgs 2 & 1 & 0 \\
Sgs 3 & 1 & 1 \\
Sgs 4 & 0 & 0 \\
Sgs 5 & 0 & 1 \\
Sgs 6 & 1 & 0 \\
Sgs 7 & 1 & 0 \\
Sgs 8 & 0 & 1 \\
Sgs 9 & 1 & 0 \\
Sgs 10 & 1 & 1 \\
\hline Control group subject 1 (Cgs 1) & 2 & 2 \\
Cgs 2 & 1 & 1 \\
Cgs 3 & 2 & 2 \\
Cgs 4 & 2 & 1 \\
Cgs 5 & 2 & 1 \\
Cgs 6 & 1 & 2 \\
Cgs 7 & 2 & 2 \\
Cgs 8 & 1 & 2 \\
Cgs 9 & 1 & 1 \\
Cgs 10 & 2 & 2 \\
\hline
\end{tabular}




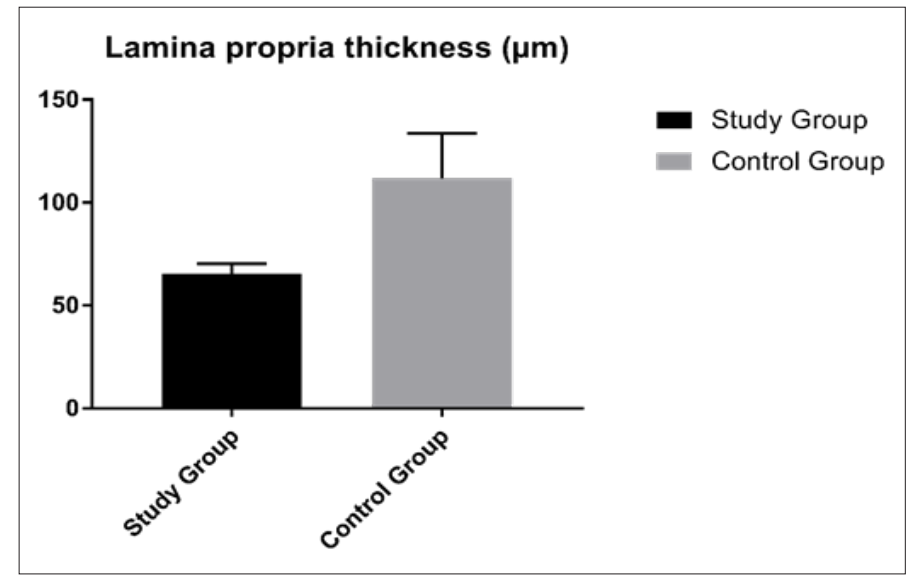

Figure 4. Comparison of inflammation and fibrosis mean score between the study and the control subjects.

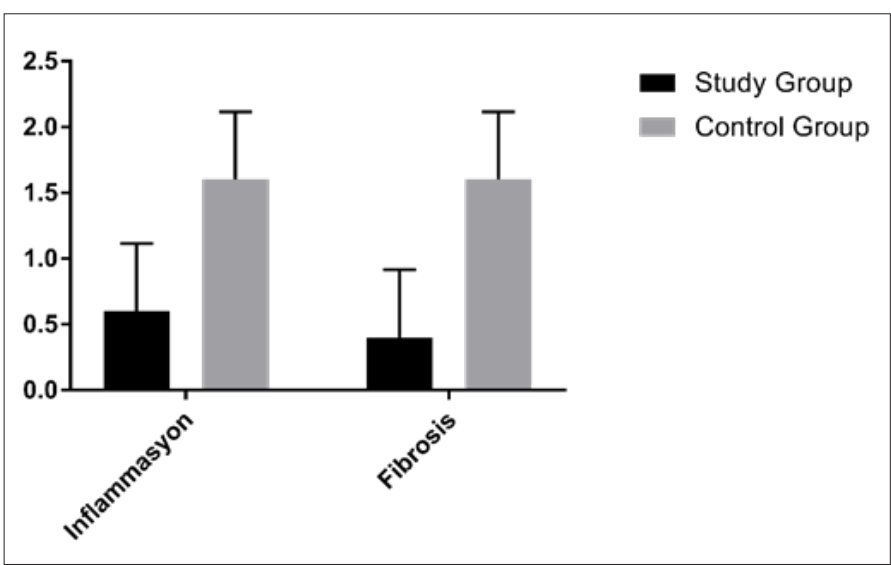

Figure 5. Comparison of lamina propria mean thickness between the study and the control subjects.

Table 3. Distribution of lamina propria thicknesses between the study and control subjects.

\begin{tabular}{lc} 
Experimental subjects & Lamina propria thickness $(\boldsymbol{\mu m})$ \\
\hline Sgs 1 & 64 \\
Sgs 2 & 64 \\
Sgs 3 & 60 \\
Sgs 4 & 68 \\
Sgs 5 & 60 \\
Sgs 6 & 63 \\
Sgs 7 & 62 \\
Sgs 8 & 65 \\
Sgs 9 & 72 \\
Sgs 10 & 65 \\
\hline Cgs 1 & 88 \\
Cgs 2 & 89 \\
Cgs 3 & 110 \\
Cgs 4 & 98 \\
Cgs 5 & 94 \\
Cgs 6 & 147 \\
Cgs 7 & 133 \\
Cgs 8 & 135 \\
Cgs 9 & 96 \\
Cgs 10 & 128 \\
\hline
\end{tabular}

\section{DISCUSSION}

Inflammatory changes were investigated experimentally in subjects with acute otitis media. ALA was administered to the study group to investigate changes after treatment. Mucosal thickness, inflammation and fibrosis values were significantly improved in the study group.

Tissue injury at the submucosal level is responsible for the development of Ts. Agents that cause this damage include acute and chronic infections and all middle ear traumas, particularly surgical traumas. Genetic and autoimmune disorders are also considered to play a role in the etiopathology of the disease. ${ }^{[10]}$

SomestudieshaveimplicatedType III hypersensitivityreactions as the mechanism involved in Ts. A passive sensitivity was established in the lamina propria of the tympanic membrane. New active autoantibodies were added to autoantibodies with passive sensitivity through paracentesis, physical trauma and severe infection. At this point, tissue injury occurred due to Type III hypersensitivity. Abundant local degenerated elements remaining from diffuse ulceration and necrosis occurring in the tympanic membrane and middle ear were reported to trigger tympanosclerosis changes. ${ }^{[11-13]}$

Another factor involved in the development of Ts is middle ear infections. Ts generally occurs in the final stage of chronic or recurrent infections of the middle ear. ${ }^{[14]}$ In different series, the levels of development of Ts in various types of otitis media have been reported to be between $20 \%$ and $43 \%$. $^{[15-18]}$ In the early stage of inflammation, the tympanic membrane and middle ear mucosa are infiltrated by numerous inflammatory cells, such as macrophages, as a response to injury. These cells are organized with fibrous tissue in the final stages of inflammation and lead to inflammation-related Ts characterized by hyalinization and calcification. ${ }^{[19]}$ The development of inflammation-related Ts has been reported at levels of $24.2 \%$ in chronic otitis media, $16.6 \%$ in otitis media with effusion and $5 \%$ in purulent acute otitis media. ${ }^{[20]}$ Another study reported the rates of Ts as $43 \%$ in patients with chronic otitis media with tympanic membrane perforation and $19.6 \%$ in patients with chronic otitis media without perforation. ${ }^{[18]}$ We used the sclerosis enhancing effect of middle ear infections to induce inflammation-related Ts in our animal models. We employed Streptococcus pneumoniae, the most common agent of otitis media, in order to induce middle ear infection.

Currently, no treatment can completely reverse the damage and clinical symptoms of Ts. The current treatment protocols have been evaluated under the headings of medical and surgical therapy. Although surgical treatment is performed in order to eliminate the adverse effects of the resulting damage on hearing, the long-term success rates are not promising. In terms of etiopathology in particular, protective treatment aimed at preventing a pathological process in the group at risk of developing Ts is still at the research stage. ${ }^{[21,22]}$ Antioxidant substances have been shown to play an important protective role in the prevention of inflammation-related Ts. Therefore, in this study, we evaluated the effectiveness of ALA as an antioxidant.

A hyperoxide state in the middle ear cavity causes myringosclerosis by increasing the production of free oxygen radicals. Oxygen saturation at normal levels of 5-10\% in the middle ear cavity may rise to $21 \%$ when myringotomy is performed. This relative hyperoxide state may increase the 
oxygen-derived free radicals. At the same time, an increase in nitric oxide levels is observed secondary to middle ear inflammation. Nitric oxide is converted into highly harmful nitrogen dioxide by reacting with $\mathrm{O}_{2}$ in increased concentrations of oxygen and constitutes the basis for the development of sclerotic structures. Inflammatory reactions have also been observed in the tympanic membrane during the same period. Therefore, it is considered that myringosclerosis can be prevented with the use of antioxidants and reducing or anti-inflammatory agents. ${ }^{[21]}$ Mattson et al. ${ }^{[4]}$ evaluated the effect of the hyperoxide state at different oxygen concentrations in myringotomized rats. Higher levels of Ts were observed in rats exposed to high oxygen concentrations. Various in vivo and in vitro models have been used to elucidate the antioxidant effects mechanisms of ALA. When applied exogenically, ALA exhibits antioxidant activities such as free radical scavenging, metal chelation and increasing the regeneration of endogenous antioxidant such as glutathione. [23] Various studies have shown the effects of ALA in reducing type II diabetes, hepatic toxicity and neuronal injury. ${ }^{[24-27]}$ In our study, we investigated the effect of ALA on experimentally induced Ts in rats. Exogenous ALA in diet has been found capable of reducing the development of Ts.

\section{CONCLUSION}

In conclusion, ALA, which exhibits antioxidant properties, appears to be capable of preventing experimentally induced inflammation-related Ts. Antioxidant molecule (ALA) absorbed from medically administered may therefore prevent or reduce the development of inflammation-related Ts.

\section{ETHICAL DECLARATIONS}

Ethics Comittee Approval: The study was carried out with the permission of local Ethical committee approval was obtained to conduct the study (2013 HADYEK 018) in the Experimental Medicine Research laboratory of Gaziosmanpaşa University, Turkey.

Informed Consent: Written informed consent was obtained from all participants who participated in this study.

Status of Peer-review: Externally peer-reviewed.

Conflict of Interest Statement: The authors have no conflicts of interest to declare.

Financial Disclosure: The authors declared that this study has received no financial support.

Author Contributions: All of the authors declare that they have all participated in the design, execution, and analysis of the paper, and that they have approved the final version.

\section{REFERENCES}

1. Pulec JL, Deguine C. Long-term ventilating tube with tympanosclerosis. Ear Nose Throat J. 2000; 79: 680.

2. Koç $A$, Uneri C. Genetic predisposition for tympanosclerotic degeneration. Eur Arch Otorhinolaryngol. 2002 ;259: 180-3.

3. Karlidag T, Ilhan N, Kaygusuz I, Keles E, Yalcin S. Comparisson of free radicals and antioxidant enzymes in chronic otitis media with and without tympanosclerosis. Laryngoscope 2004; 114: 85-9.

4. Mattsson C, Magnusson K, Hellstrom S. Myringosclerosis caused by increased oxygen concentration in traumatized tympanic membranes, experimental study. Ann Otol Rhinol Laryngol 1995; 104: 625-32.
5. Han D, Handelman G, Marcocci L, Sen CK, Roy S, Kobuchi H et al. Lipoic acid increases de novo synthesis of cellular glutathione by improving cystine utilization. Biofactors. 1997; 6: 321-38.

6. Moini H, Packer L, Saris NE. Antioxidant and prooxidant activities of alphalipoic acid and dihydrolipoic acid. Toxicol. Appl. Pharmacol. 2002; 182: 8490.

7. Ghibu S, Richard C, Vergely C, Zeller M, Cottin Y, Rochette L. Antioxidant properties of an endogenous thiol: alpha-lipoic acid, useful in the prevention of cardiovascular diseases. J Cardiovasc Pharmacol. 2009; 54(5): 391-398.

8. Packer L, Witt EH, Tritschler HJ. a-Lipoic acid as a biological antioxidant. Free Radic. Biol. Med. 1995; 19: 227-50.

9. Toklu HZ, Hakan T, Celik H, Biber N, Erzik C, Ogunc AV, et al. Neuroprotective effects of alpha-lipoic acid in experimental spinal cord injury in rats. J Spinal Cord Med. 2010; 33(4): 401-9.

10. Forse'ni M, Bagger-Sjöback D, HultcrantzM. A study of inflamatory mediators in the human tympanosclerotic middle ear. Arch Otolaryngol Head Neck Surg. 2001; 127: 559-64.

11. Morgan WC. Tympanosclerosis. Laryngoscope 1977; 87: 1821-5.

12. Schiff M, Poliquin JF, Catanzaro A, Ryan AF. Tympanosclerosis. A theory of pathogenesis. Ann Otol Rhinol Laryngol Suppl 1980; 89: 1-16.

13. Forseni M, Bagger-Sjöback D, Hultcrantz M. A study of inflammatory mediators in the human tympanosclerotic middle ear. Arch Otolaryngol Head Neck Surg 2001; 127: 559-64.

14. Leal MC, Neto SSC, Caldas N, Peixoto CA, Lessa FJD, Leao BT, et al. Influence of hypercalsemia in the formation of tympanosclerosis in rat. Otol Neurotol 2005; 27: 27-32.

15. Tos M. Stangerup SE. Hearing loss in tympanosclerosis caused by grommets. Arch Otolaryngol Head Neck Surg 1989; 115: 9315

16. Sheehy JL, House WF. Tympanosclerosis. Arch Otolaryngol 1962; 76: $151-$ 7.

17. Tos M, Bak-Pedersen K. Middle-ear mucosa in tympanosclerosis. J Laryngol Otol 1974; 88: 119-26.

18. Costa SS, Paparella MM, Schachern PA, Yoon TH, Kimberley BP. Temporal bone histopathology in chronically infected ears with intact and perforated tympanic membranes. Laryngoscope 1992; 102: 1229-36.

19. Makiishi-Shimobayashi C, Tsujimura T, Sugihara A, Iwasaki T, Yamada N, Terada N, Sakagami M. Expression of osteopontin by exudate macrophages in infammatory tissues of the middle ear: a possible association with development of tympanosclerosis. Hear Res. 2001; 153: 100-7.

20. Bhaya MH, Schachern PA, Morizono T, Paparella MM. Pathogenesis of tympanosclerosis. Otolaryngol Head Neck Surg. 1993; 109: 413-20.

21. Polat S, Oztürk O, Uneri C, Yüksel M, Haklar G, Bozkurt $S$, et all. Determination of Reactive Oxygen Species in Myringotomized Tympanic Membranes: Effect of Vitamin ETreatment. Laryngoscope. 2004; 114: 720 5.

22. Albu S, Babighian G, and Trabalzini F. Surgical Treatment of Tympanosclerosis. The American Journal of Otology 2000; 21: 631-5.

23. Çakatay U. Pro-oxidant actions of a-lipoic acid and dihydrolipoic acid. Med Hypotheses. 2006; 66: 110-7.

24. Thirunavukkarasu V, Anuradha CV. Influence of alpha-lipoic acid on lipid peroxidation and antioxidant defence system in blood of insulin-resistant rats. Diabetes Obes Metab. 2004; 6: 200-7.

25. Arivazhagan P, Ramanathan K, Panneerselvam C. Effect of DLalpha-lipoic acid on mitochondrial enzymes in aged rats. Chem Biol Interact. 2001; 138: 189-98.

26. Khanna S, Atalay M, Laaksonen DE, Gul M, Roy S, Sen CK. Alphalipoic acid supplementation: tissue glutathione homeostasis at rest and after exercise. J Appl Physiol. 1999; 86: 1191-6.

27. Cummings BP, Stanhope KL, Graham JL, Evans JL, Baskin DG, Griffen SC, et al. Dietary fructose accelerates the development of diabetes in UCD-T2DM rats: amelioration by the antioxidant, alpha-lipoic acid. Am J Physiol Regul Integr Comp Physiol 2010; 298: 1343-50. 